\title{
PENGARUH KONSENTRASI OLEORESIN DAN KOMPOSISI BAHAN PENYALUT TERHADAP KARAKTERISTIK MIKROKAPSUL OLEORESIN JAHE EMPRIT (Zingiber officinale) DENGAN METODA SPRAY DRYING
}

\author{
Nhadira Nhestricia \\ Program Studi Farmasi FMIPA-UNPAK
}

\begin{abstract}
ABSTRAK
Oleoresin merupakan campuran kompleks dari bahan volatile dan bahan nonvolatil yang memberikan aroma dan rasa khas pada jahe (Zingiber officinale). Oleoresin memiliki sifat sangat lengket, kental dan sulit ditakar sehingga efisiensi pemanfaatannya dalam skala industri menjadi berkurang. Masalah ini dapat diatasi dengan melakukan mikroenkapsulasi untuk mengkonversi oleoresin (zat cair) menjadi serbuk (zat padat). Tujuan penelitian ini adalah untuk membuat mikrokapsul oleoresin jahe dengan penyalut natrium kaseinat dan maltodekstrin menggunakan teknik spray drying dan mempelajari karakteristik oleoresin jahe terenkapsulasi. Penelitian ini dilakukan dalam 2 tahap, yaitu penelitian pendahuluan dan penelitian utama. Pada tahap 1, oleoresin konsentrasi $5 \%$ dan $25 \%$ dienkapsulasi dengan penyalut natrium kaseinat dan maltodekstrin pada komposisi 7,5\%:92,5\% dan 30\%:70\%. Pada tahap 2, konsentrasi oleoresin dinaikan secara bertahap mulai dari 5\%,10\%, 15\%, sampai $20 \%$ dengan komposisi penyalut na-kaseinat dan maltodekstrin 7,5\%:92,5\% dan 30\%:70\%. Pengamatan terhadap mikrokapsul oleoresin jahe meliputi pengukuran total oil (kadar minyak atsiri), oil recovery (perolehan minyak kembali), surface oil (kadar minyak di permukaan mikrokapsul), kadar air, dan bentuk partikel mikrokapsul dengan scanning electron microscope. Mikrokapsul oleoresin jahe terbaik diperoleh pada penggunaan oleoresin konsentrasi $10 \%$ menggunakan penyalut natrium kaseinat:maltodekstrin 7,5\%:92,5\% dengan karakteristk total oil 2,34\%, oil recovery $87,50 \%$, surface oil $0,27 \%$, dan kadar air 4,97\%.
\end{abstract}

Kata kunci : Jahe emprit, oleoresin, mikrokapsul

\section{THE EFFECT OF OLEORESIN CONCENTRATION AND ENCAPSULANTS COMPOSITION ON CHARACTERISTIC OF GINGER (Zingiber officinale) OLEORESIN MICROCAPSULE USING SPRAY DRYING}

\author{
Nhadira Nhestricia \\ Program Studi Farmasi FMIPA-UNPAK
}

\begin{abstract}
Oleoresin is a complex mixture of volatile and non-volatile materials that give a distinctive aroma and flavor to the ginger (Zingiber officinale).Oleoresin has a very sticky, viscous and hard-to-burn properties so that its industrial utilization efficiency is reduced. Microencapsulation by spray drying has been done with purpose to convert oleoresin (liquid) into powder (solid). The aim of this research are to make microcapsule of ginger oleoresin by spray drying, to determine oleoresin and
\end{abstract}


encapsulants concentration at optimal condition, and to study the characteristic of ginger oleoresin microcapsule. The research is done in two stages. On the pre-research, the oleoresin is tested using 2 concentration, $5 \%$ and $25 \%$ with 2 compositions of encapsulants, which the compare persentation of sodium caseinate:maltodextrin are 7.5\%:92.5\% and 30\%:70\%. At the main research, oleoresin concentration is derivated from $25 \%$ onto 4 scales, started from $5 \%, 10 \%, 15 \%$, and $20 \%$ with 2 compositions of encapsulants, sodium caseinate:maltodextrin are 7.5\%:92.5\% and 30\%:70\%. The observation has been done to total oil, oil recovery, surface oil, water content and the particle form of microcapsule by scanning electron microscope. The best treatment is raised on oleoresin concentration $10 \%$ and composition of encapsulants, sodium caseinate:maltodextrin is $7.5 \%: 92.5 \%$, that result $2.34 \%$ in total oil, $87.50 \%$ in oil recovery, $0.27 \%$ in surface oil, and $4.97 \%$ in water content.

Key words : Microencapsulation, Ginger Oleoresin, Encapsulants, Spray Drying

\section{PENDAHULUAN}

Sebagian besar masyarakat Indonesia memanfaatkan rimpang jahe sebagai bumbu masak dan zat tambahan pada makanan dan minuman. Secara empiris rimpang jahe digunakan pula untuk berbagai pengobatan tradisional, seperti untuk mengobati selesma, batuk, diare, penyakit radang sendi tulang (seperti arthritis), dan meningkatkan pembersihan tubuh melalui keringat.

Khasiat-khasiat rimpang jahe berasal dari berbagai senyawa bioaktif yang terdapat dalam rimpang jahe. Dari hasil analisa, diketahui bahwa senyawasenyawa bioaktif pada rimpang jahe antara lain minyak atsiri, oleoresin, dan gingerol (senyawa yang menyebabkan bau harum khas jahe). Senyawa penting yang paling banyak digunakan dalam industri farmasi, makanan, dan minuman dari rimpang jahe adalah oleoresin, yang terdiri dari minyak atsiri (penentu aroma) serta resin dan gum (pembentuk rasa) (Koswara, 2006).

Luasnya pemanfaatan oleoresin dalam produk-produk farmasi, makanan, dan minuman mengharuskan adanya efektifitas penggunaan oleoresin dalam produk-produk tersebut. Sifat-sifat fisik oleoresin yang kental cukup menyulitkan pengguna dalam penyimpanan jangka panjang karena mudah terpengaruh oleh oksidasi $\mathrm{O}_{2}$, cahaya dan kelembaban. Sifat fisik yang lengket dan kental juga menyulitkan proses penakaran dan pencampuran oleoresin dengan bahanbahan lain dalam suatu produk (Koswara, 2006). Hal-hal tersebut mengakibatkan perlunya penanganan khusus dalam penggunaan oleoresin. Sifat oleoresin yang tidak stabil terhadap perubahan lingkungan mengharuskan oleoresin disimpan dalam kondisi optimal menggunakan wadah gelas bertutup yang berwarna gelap, pada suhu cukup rendah. Dalam skala industri, penanganan dan penyimpanan oleoresin menjadi faktor yang mempengaruhi efisiensi penggunaan oleoresin.

Untuk mengefektifkan manfaat dari jahe tersebut, maka bentuk oleoresin yang semula cairan kental, dikonversi ke bentuk solid berupa serbuk atau granul. Perkembangan ilmu pengetahuan dan teknologi telah mampu menghasilkan mikroenkapsulasi, suatu teknologi yang memungkinkan dilakukannya pengkonversian zat cair menjadi serbuk zat padat. Dalam bidang farmasi, oleoresin terenkapsulasi dapat diformulasikan sebagai zat aktif dalam berbagai sediaan, seperti sediaan cair dan sediaan semi solid, ataupun sebagai zat 
tambahan dalam makanan dan minuman sehingga efek samping dari bahan sintetis dan semisintetis yang cenderung sering digunakan dapat dieliminasi.

Dalam penelitian ini dibuat oleoresin jahe terenkapsulasi dengan empat konsentrasi oleoresin dan dua komposisi bahan penyalut. Bentuk oleoresin terenkapsulasi memiliki keunggulan, antara lain untuk melindungi bahan aktif dari pengaruh lingkungan yang merugikan dan untuk mengontrol pelepasan (time release) zat aktif. Mikroenkapsulasi oleoresin jahe dilakukan dengan metode spray drying, yang melibatkan penggunaan kombinasi natrium kaseinat dan maltodekstrin dalam aquadest sebagai bahan penyalut. Mikrokapsul oleoresin jahe kemudian dianalisis untuk mengetahui karakteristiknya.

\section{BAHAN DAN METODE Bahan}

Bahan-bahan yang digunakan terdiri atas rimpang jahe kecil, emprit, natrium kaseinat, maltodekstrin, etanol 96\%, heksana, toluen dan aquadest.

\section{Alat}

Timbangan digital, mesin penggiling disc-mill, ayakan mesh ukuran 40-60, oven, rotary vacuum evaporator, homogenizer, Viscometer Brookfield, mesin spray drier.

\section{Metode Kerja}

Ekstraksi

oleoresin jahe memerlukan bahan dalam bentuk serbuk kering. Pembuatan serbuk jahe (powdering) dilakukan dengan cara merajang rimpang jahe segar dengan tebal irisan 5-8 $\mathrm{mm}$, kemudian dikeringkan di dalam oven dengan suhu $60^{\circ} \mathrm{C}$ selama $2 \mathrm{x}$ 8 jam. Jahe yang telah kering digiling menggunakan penggiling disc-mill dengan ayakan mesh 40-60. Serbuk jahe kemudian diekstraksi secara maserasi dengan melarutkannya dalam etanol teknis 96\% dengan perbandingan 1:6 dan diaduk menggunakan pengaduk mekanik selama 2 jam dengan kecepatan 150 RPM kemudian didiamkan selama 24 jam.

Selanjutnya ekstrak dipisahkan dari ampasnya dengan cara menyaring menggunakan kertas saring. Ekstrak menggunakan rotary vacuum evaporator (rotavapor) pada suhu $60^{\circ} \mathrm{C}$ dan tekanan 0,57 bar (100 x $\mathrm{KPa} \mathrm{Hg})$ sampai semua pelarut menguap, terkondensasi kembali menjadi cairan dan ditampung dalam labu penampungan pelarut. Sisa yang tertinggal dalam labu dimasukkan ke dalam oven vacum suhu $60^{\circ} \mathrm{C}$ selama 2 jam, kemudian didinginkan dan ditimbang. Selanjutnya dilakukan analisis terhadap oleoresin, yang meliputi rendemen oleoresin, berat jenis, kadar minyak atsiri, residu pelarut dan kadar air. Diagram alir pembuatan oleoresin jahe disajikan pada Gambar 1.

Pembuatan suspensi bahan penyalut dilakukan dengan mencampurkan larutan maltodekstrin ke dalam larutan natrium kaseinat dengan perbandingan komposisi natrium kaseinat dan maltodekstrin adalah 7,5\%:92,5\% dan 30\%:70\% dalam aquadest dengan total padatan $20 \%$. Natrium kaseinat dilarutkan dalam aquadest hangat suhu $60^{\circ} \mathrm{C}$ menggunakan homogenizer dengan kecepatan rendah (100 RPM). Selanjutnya suspensi bahan penyalut dihidrasi selama 18 jam.

Setelah hidrasi bahan penyalut, untuk penelitian pendahuluan, ke dalamnya dilakukan pembentukan emulsi oleoresin jahe dengan konsentrasi $5 \%$ dan $25 \%$ dari total padatan bahan penyalut menggunakan homogenizer berkecepatan 6000 RPM selama lebih kurang 30 menit. Komposisi perlakuan penelitian pendahuluan dapat dilihat pada Tabel 1 . Selanjutnya diukur viskositas emulsi menggunakan Viscometer Brookfield dengan putaran 100 RPM kemudian dikeringkan dengan spray drier pada suhu inlet $160^{\circ} \mathrm{C}$ dan suhu outlet $100^{\circ} \mathrm{C}$. Serbuk 
yang dihasilkan merupakan mikrokapsul yang siap untuk dianalisis. Hasil terbaik dijadikan acuan untuk penetapan komposisi pada penelitian utama (Tabel 2). Diagram alir mikroenkapsulasi penelitian utama disajikan pada Gambar 2. Mikrokapsul yang terbentuk selanjutnya dianalisis terhadap total oil, oil recovery, surface oil, kadar air, dan bentuk partikel di bawah scanning electron microscope. Data total oil, oil recovery, dan surface oil dianalisis dengan Analisis Sidik Ragam untuk Rancangan Acak Lengkap Faktorial 4x2 dan diuji lanjut dengan Uji Duncant.

Tabel 1. Komposisi Formula pada Penelitian Pendahuluan

\begin{tabular}{|c|c|c|c|c|c|}
\hline \multicolumn{2}{|c|}{ Komposisi } & \multicolumn{4}{|c|}{ Formula } \\
\hline & & $\mathrm{O}_{5} \underline{\mathrm{N}}_{7,5}$ & $\mathrm{O}_{5} \underline{\mathrm{N}}_{30}$ & $\mathrm{O}_{25} \underline{\mathrm{N}}_{7,5}$ & $\mathrm{O}_{25} \underline{\mathrm{N}}_{30}$ \\
\hline \multicolumn{2}{|c|}{ Oleoresin } & $12 \mathrm{~g}$ & $12 \mathrm{~g}$ & $60 \mathrm{~g}$ & $60 \mathrm{~g}$ \\
\hline Bahan & Na-kaseinat & $18 \mathrm{~g}$ & $72 \mathrm{~g}$ & $18 \mathrm{~g}$ & $72 \mathrm{~g}$ \\
\hline \multirow[t]{3}{*}{ Suspensi } & Maltodekstrin & $222 \mathrm{~g}$ & $168 \mathrm{~g}$ & $222 \mathrm{~g}$ & $168 \mathrm{~g}$ \\
\hline & Aquadest & $960 \mathrm{~g}$ & $960 \mathrm{~g}$ & $960 \mathrm{~g}$ & $960 \mathrm{~g}$ \\
\hline & Total & $1.212 \mathrm{~g}$ & $1.212 \mathrm{~g}$ & $1.260 \mathrm{~g}$ & $1.260 \mathrm{~g}$ \\
\hline
\end{tabular}

Ket: $\quad \mathrm{O}_{5} \mathrm{~N}_{7,5}:$ Konsentrasi oleoresin $5 \%$, na-kaseinat 7,5\%

$\mathrm{O}_{5} \mathrm{~N}_{30}$ : Konsentrasi oleoresin 5\%, na-kaseinat 30\%

$\mathrm{O}_{25} \mathrm{~N}_{7,5}$ : Konsentrasi oleoresin 25\%, na-kaseinat 7,5\%

$\mathrm{O}_{25} \mathrm{~N}_{30}$ : Konsentrasi oleoresin 25\%, na-kaseinat $30 \%$

Tabel 2. Komposisi Formula pada Penelitian Utama

\begin{tabular}{|c|c|c|c|c|c|c|c|c|c|}
\hline \multirow{2}{*}{\multicolumn{2}{|c|}{ Bahan }} & \multicolumn{8}{|c|}{ Perlakuan } \\
\hline & & $\mathrm{O}_{5} \underline{\mathrm{N}}_{7,5}$ & $\mathrm{O}_{5} \underline{\mathrm{N}}_{30}$ & $\mathrm{O}_{10} \underline{\mathrm{N}}_{7,5}$ & $\mathrm{O}_{10} \underline{\mathrm{N}_{30}}$ & $\mathrm{O}_{15} \underline{N}_{7,5}$ & $\mathrm{O}_{15} \underline{\mathrm{N}}_{30}$ & $\mathrm{O}_{20} \underline{\mathrm{N}_{7,5}}$ & $\mathrm{O}_{20} \underline{\mathrm{N}_{30}}$ \\
\hline \multicolumn{2}{|c|}{ Oleoresin } & $12 \mathrm{~g}$ & $12 \mathrm{~g}$ & $24 \mathrm{~g}$ & $24 \mathrm{~g}$ & $36 \mathrm{~g}$ & $36 \mathrm{~g}$ & $48 \mathrm{~g}$ & $48 \mathrm{~g}$ \\
\hline Bahan & $\mathrm{Na}$ kaseinat & $18 \mathrm{~g}$ & $72 \mathrm{~g}$ & $18 \mathrm{~g}$ & $72 \mathrm{~g}$ & $18 \mathrm{~g}$ & $72 \mathrm{~g}$ & $18 \mathrm{~g}$ & $72 \mathrm{~g}$ \\
\hline \multirow[t]{3}{*}{ Suspensi } & Maltodekstrin & $222 \mathrm{~g}$ & $168 \mathrm{~g}$ & $222 \mathrm{~g}$ & $168 \mathrm{~g}$ & $222 \mathrm{~g}$ & $168 \mathrm{~g}$ & $222 \mathrm{~g}$ & $168 \mathrm{~g}$ \\
\hline & Aquadest & $960 \mathrm{~g}$ & $960 \mathrm{~g}$ & $960 \mathrm{~g}$ & $960 \mathrm{~g}$ & $960 \mathrm{~g}$ & $960 \mathrm{~g}$ & $960 \mathrm{~g}$ & $960 \mathrm{~g}$ \\
\hline & tal & $1.212 \mathrm{~g}$ & $1.212 \mathrm{~g}$ & $1.224 \mathrm{~g}$ & $1.224 \mathrm{~g}$ & $1.236 \mathrm{~g}$ & $1.236 \mathrm{~g}$ & $1.248 \mathrm{~g}$ & $1.248 \mathrm{~g}$ \\
\hline
\end{tabular}

Ket: $\quad \mathrm{O}_{5} \mathrm{~N}_{7,5}:$ Konsentrasi oleoresin $5 \%$, na-kaseinat 7,5\%

$\mathrm{O}_{5} \mathrm{~N}_{30}$ : Konsentrasi oleoresin 5\%, na-kaseinat $30 \%$

$\mathrm{O}_{10} \mathrm{~N}_{7,5}$ : Konsentrasi oleoresin $10 \%$, na-kaseinat 7,5\%

$\mathrm{O}_{10} \mathrm{~N}_{30}$ : Konsentrasi oleoresin $10 \%$, na-kaseinat $30 \%$

$\mathrm{O}_{15} \mathrm{~N}_{7,5}$ : Konsentrasi oleoresin $15 \%$, na-kaseinat 7,5\%

$\mathrm{O}_{15} \mathrm{~N}_{30}$ : Konsentrasi oleoresin $15 \%$, na-kaseinat $30 \%$

$\mathrm{O}_{20} \mathrm{~N}_{7,5}$ : Konsentrasi oleoresin 20\%, na-kaseinat 7,5\%

$\mathrm{O}_{20} \mathrm{~N}_{30}$ : Konsentrasi oleoresin 20\%, na-kaseinat $30 \%$

\section{HASIL DAN PEMBAHASAN}

Analisa yang dilakukan terhadap serbuk kering jahe menunjukkan kadar air yang lebih tinggi dibandingkan analisa terhadap oleoresin. Kadar air serbuk jahe kering adalah 5,45\% sedangkan kadar air oleoresin adalah 3,99\%. Perolehan kadar minyak atsiri yang terkandung dalam serbuk kering jahe $(1,43 \%)$ jauh lebih kecil dibandingkan dengan kadar minyak atsiri pada oleoresin (26,78\%) karena oleoresin merupakan bahan yang konsentrat. Data hasil analisa dapat dilihat pada Tabel 3. Kadar minyak atsiri bahan baku (serbuk jahe) tidak memenuhi syarat bila dibandingkan dengan standar, yaitu 23\% (Depkes, 1989). Hal ini mungkin disebabkan oleh jahe yang digunakan 
adalah jahe muda yang masih berumur 4 bulan sehingga kandungan minyak atsirinya belum maksimal. Kandungan minyak atsiri akan maksimal pada jahe yang berumur 9-10 bulan.

Tabel 3. Data Analisa Bahan Baku

\begin{tabular}{ccc}
\hline Parameter & $\begin{array}{c}\text { Serbuk } \\
\text { Jahe } \\
\text { Emprit }\end{array}$ & $\begin{array}{c}\text { Oleoresin } \\
\text { Jahe Emprit }\end{array}$ \\
\hline Kadar Air & $5,45 \%$ & $3,99 \%$ \\
Kadar Minyak & $1,43 \%$ & $26,78 \%$ \\
Atsiri & & \\
Residu Pelarut & - & $2,99 \%$ \\
Rendemen & - & $6,17 \%$ \\
Ekstraksi & & 1,125 \\
Berat Jenis & - & \\
\hline
\end{tabular}

\section{Analisa Penelitian Pendahuluan}

Penelitian pendahuluan telah dilakukan untuk menentukan konsentrasi maksimum oleoresin yang dapat menghasilkan mikrokapsul dengan karakteristik yang baik. Penelitian dilakukan dalam empat komposisi, yaitu penggunaan konsentrasi oleoresin dan natrium kaseinat adalah 5\% dan 7,5\%; 5\% dan $30 \%$; $25 \%$ dan $7,5 \%$; serta $25 \%$ dan $30 \%$. Parameter yang diukur meliputi viskositas emulsi, total oil, oil recovery, surface oil, dan kadar air dengan hasil sebagai berikut:

1. Peningkatan persentase oleoresin dan natrium kaseinat memberikan hasil pengukuran viskositas emulsi yang meningkat.

Viskositas emulsi pada $\mathrm{O}_{5} \mathrm{~N}_{7,5}$ dan $\mathrm{O}_{25} \mathrm{~N}_{7,5}$ adalah $30,8 \mathrm{cp}$ dan $33,6 \mathrm{cp}$; sedangkan pada $\mathrm{O}_{5} \mathrm{~N}_{30}$ dan $\mathrm{O}_{25} \mathrm{~N}_{30}$ masing-masing 54,2cp dan 54,6cp.

2. Peningkatan persentase oleoresin dan natrium kaseinat menunjukkan hasil total oil yang tinggi pula.

Pada $\mathrm{O}_{5} \mathrm{~N}_{7,5}$ dan $\mathrm{O}_{5} \mathrm{~N}_{30}$ didapatkan perolehan kadar total oil yang sama, yaitu $1,17 \%$ sedangkan pada $\mathrm{O}_{25} \mathrm{~N}_{7,5}$ dan $\mathrm{O}_{25} \mathrm{~N}_{30}$ diperoleh kadar total oil yang lebih tinggi, yaitu $2,49 \%$ dan $3,62 \%$.

3. Peningkatan persentase oleoresin memberikan hasil perhitungan oil recovery yang menurun namun peningkatan natrium kaseinat menunjukkan peningkatan oil recovery.

Pada $\mathrm{O}_{5} \mathrm{~N}_{7,5}$ dan $\mathrm{O}_{5} \mathrm{~N}_{30}$ diperoleh hasil yang sama, yaitu 90,00\%. Pada $\mathrm{O}_{25} \mathrm{~N}_{7,5}$ dan $\mathrm{O}_{25} \mathrm{~N}_{30}$ diperoleh hasil $37,50 \%$ dan $54,00 \%$.

4. Peningkatan persentase oleoresin akan meningkatkan surface oil namun hal ini tidak berlaku pada peningkatan persentase natrium kaseinat.

Pada $\mathrm{O}_{5} \mathrm{~N}_{7,5}$ dan $\mathrm{O}_{5} \mathrm{~N}_{30}$ diperoleh hasil $0,12 \%$ dan $0,21 \%$ sedangkan pada $\mathrm{O}_{25} \mathrm{~N}_{7,5}$ dan $\mathrm{O}_{25} \mathrm{~N}_{30}$ diperoleh hasil $2,38 \%$ dan $1,42 \%$.

5. Penggunaan natrium kaseinat $30 \%$ memberikan hasil kadar air yang lebih baik dibandingkan pada penggunaan natrium kaseinat $7,5 \%$.

Pada $\mathrm{O}_{5} \mathrm{~N}_{7,5}$ dan $\mathrm{O}_{25} \mathrm{~N}_{7,5}$ diperoleh hasil pengukuran kadar air 6,00\% dan $6,95 \%$ sedangkan pada $\mathrm{O}_{5} \mathrm{~N}_{30}$ dan $\mathrm{O}_{25} \mathrm{~N}_{30}$ diperoleh hasil $5,97 \%$ dan $4,48 \%$.

\section{Analisa Penelitian Utama}

Analisa produk pada penelitian utama serupa dengan analisa pada penelitian pendahuluan. Parameter yang diukur meliputi viskositas emulsi oleoresin dalam bahan penyalut sebelum proses spray drying, rendemen produk spray drying, total oil, oil recovery, surface oil, kadar air dan bentuk partikel mikrokapsul di bawah scanning electron microscope. Data lengkap hasil analisa penelitian utama tersaji dalam Tabel 4. 
Tabel 4. Data hasil analisa penelitian utama

\begin{tabular}{|c|c|c|c|c|c|c|c|c|}
\hline \multicolumn{2}{|c|}{ Perlakuan } & \multirow[b]{2}{*}{ Kode } & \multirow{2}{*}{$\begin{array}{c}\text { Viskositas } \\
\text { Emulsi } \\
(\mathrm{cp})\end{array}$} & \multirow{2}{*}{$\begin{array}{c}\text { Rendemen } \\
\text { Spray Dried } \\
(\%) \\
\end{array}$} & \multirow{2}{*}{$\begin{array}{c}\text { Total } \\
\text { Oil } \\
(\%) \\
\end{array}$} & \multirow{2}{*}{$\begin{array}{c}\text { Oil } \\
\text { Recovery } \\
(\%)\end{array}$} & \multirow{2}{*}{$\begin{array}{c}\text { Surface } \\
\text { Oil } \\
(\%) \\
\end{array}$} & \multirow{2}{*}{$\begin{array}{c}\text { Kadar } \\
\text { Air } \\
(\%) \\
\end{array}$} \\
\hline $\begin{array}{c}\mathbf{O} \\
(\%) \\
\end{array}$ & $\begin{array}{c}\mathbf{N} \\
(\%)\end{array}$ & & & & & & & \\
\hline 5 & \multirow{4}{*}{7,5} & $\overline{\mathrm{O}_{5} \mathrm{~N}_{7,5}}$ & 30,8 & 85,19 & $1,17 \mathrm{a}$ & 90,00 cdefgh & $0,12 \mathrm{a}$ & 6,00 \\
\hline 10 & & $\mathrm{O}_{10} \mathrm{~N}_{7,5}$ & 31,6 & 84,10 & 2,34 cdef & 87,50 cdefg & $0,27 \mathrm{a}$ & 4,97 \\
\hline 15 & & $\mathrm{O}_{15} \mathrm{~N}_{7,5}$ & 33,2 & 73,90 & $2,20 \mathrm{ac}$ & $54,55 \mathrm{c}$ & $1,60 \mathrm{cdef}$ & 4,97 \\
\hline 20 & & $\mathrm{O}_{20} \mathrm{~N}_{7,5}$ & 33,6 & 84,15 & $2,27 \mathrm{cde}$ & $42,12 \mathrm{a}$ & 2,05 cdefg & 5,70 \\
\hline 5 & \multirow{4}{*}{30} & $\mathrm{O}_{5} \mathrm{~N}_{30}$ & 54,2 & 80,24 & $1,17 \mathrm{a}$ & 90,00 cdefgh & $0,21 \mathrm{a}$ & 5,97 \\
\hline 10 & & $\mathrm{O}_{10} \mathrm{~N}_{30}$ & 54,8 & 81,70 & $2,20 \mathrm{c}$ & $81,48 \mathrm{cdef}$ & $0,49 \mathrm{bc}$ & 6,44 \\
\hline 15 & & $\mathrm{O}_{15} \mathrm{~N}_{30}$ & 49,6 & 77,81 & 3,07 cdefg & 76,78 cde & $1,05 \mathrm{~cd}$ & 4,72 \\
\hline 20 & & $\mathrm{O}_{20} \mathrm{~N}_{30}$ & 54,6 & 82,56 & 3,07 cdefg & $57,81 \mathrm{~cd}$ & $1,35 \mathrm{cde}$ & 5,95 \\
\hline
\end{tabular}

Ket: Angka-angka dengan huruf yang sama pada kolom yang sama tidak berbeda nyata pada taraf $5 \%$.

$\mathrm{O}=$ Konsentrasi oleoresin $(5 \%, 10 \%, 15 \%$, dan 20\%)

$\mathrm{N}=$ Konsentrasi natrium kaseinat $(7,5 \%$ dan $30 \%)$

Perolehan data hasil pengukuran viskositas emulsi oleoresin jahe sebelum proses spray drying secara umum menggambarkan bahwa penggunaan natrium kaseinat dengan konsentrasi yang tinggi meningkatkan viskositas emulsi. Sedangkan peningkatan jumlah oleoresin tidak memberikan peningkatan viskositas emulsi yang berarti.

Perhitungan rendemen terhadap basis kering (oleoresin, natrium kaseinat, dan maltodekstrin) yang diperoleh berkisar antara $73,90 \%$ sampai $85,19 \%$. Perolehan hasil bervariasi, dipengaruhi faktor alat spray drier yang tidak selamanya lancar saat proses pengeringan. Rendemen yang baik biasanya berkisar antara $80 \%$ sampai $90 \%$.

Secara umum tampak peningkatan total oil dengan meningkatnya konsentrasi oleoresin dan natrium kaseinat $(1,17 \%$ pada $\mathrm{O}_{5} \mathrm{~N}_{7,5}$ dan $3,07 \%$ pada $\mathrm{O}_{20} \mathrm{~N}_{30}$ ). Grafik Total Oil ditunjukkan pada Gambar 3.

Dari analisis statistik, diketahui bahwa total oil mikrokapsul secara umum berbeda sangat nyata antara semua perlakuan. Pengukuran total oil (kadar minyak atsiri) sangat dipengaruhi oleh jumlah oleoresin yang digunakan dalam percobaan. Semakin tinggi persentase oleoresin, maka semakin tinggi pula kadar minyak atsiri yang terkandungnya.

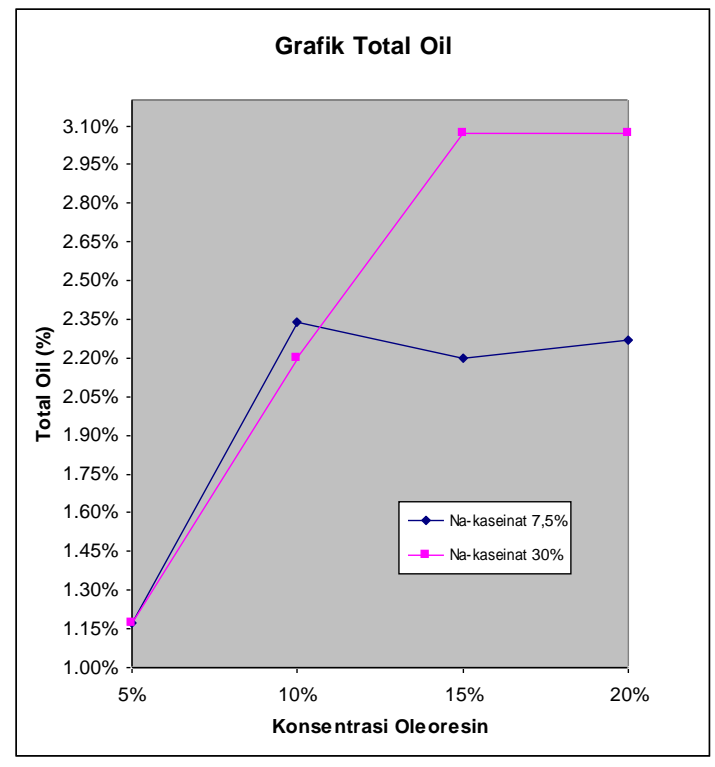

Gambar 3. Grafik Total Oil Mikrokapsul Penelitian Utama

Namun pada $\mathrm{O}_{15} \mathrm{~N}_{7,5}$ dan $\mathrm{O}_{20} \mathrm{~N}_{7,5}$ total oil yang diperoleh lebih rendah (2,20\% dan 2,27\%) dibandingkan dengan total oil pada $\mathrm{O}_{10} \mathrm{~N}_{7,5}(2,34 \%)$. Hal ini mungkin disebabkan oleh penyalutan yang kurang sempurna dengan bahan penyalut berkomposisi na-kaseinat dan maltodekstrin dengan perbandingan 7,5\%:92,5\%. Emulsi yang tidak stabil karena kurangnya emulsifier, dalam hal ini na-kaseinat, menyebabkan pecahnya emulsi yang tampak dari memisahnya oleoresin (fasa minyak) di bagian 
permukaan atas sistem emulsi. Peningkatan na-kaseinat menunjukkan hasil yang lebih baik, seperti yang diperoleh pada $\mathrm{O}_{15} \mathrm{~N}_{30}$ dan $\mathrm{O}_{20} \mathrm{~N}_{30}$ $(3,07 \%)$.

Peningkatan oleoresin menyebabkan menurunnya oil recovery (perolehan minyak kembali). Range data oil recovery yang didapat adalah $42,12 \%$ sampai $90,00 \%$. Grafik oil recovery ditunjukkan pada Gambar 4.

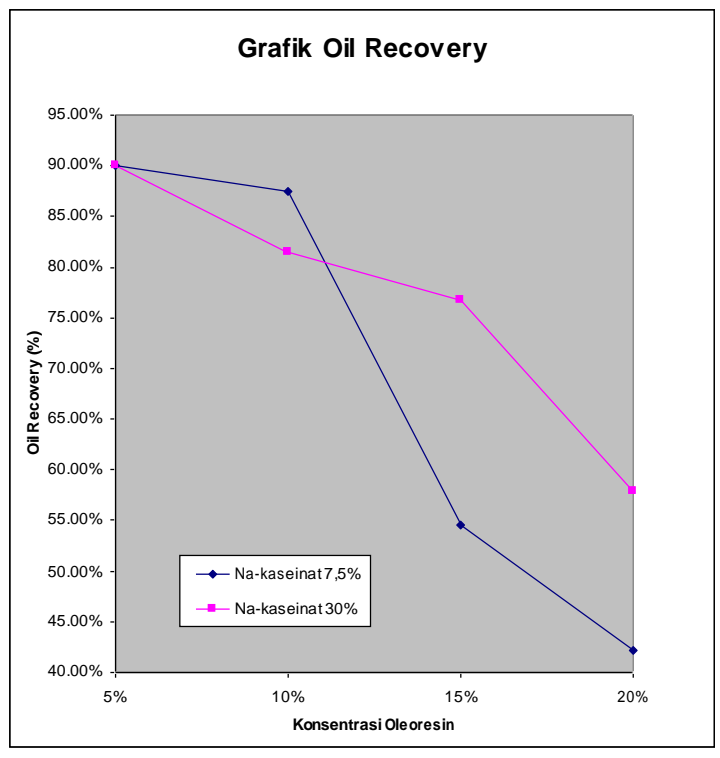

Gambar 4. Grafik Oil Recovery Mikrokapsul Penelitian Utama

Menurunnya oil recovery pada peningkatan konsentrasi oleoresin disebabkan oleh kemampuan bahan penyalut yang mencapai titik maksimal pada konsentrasi oleoresin rendah (5\%) dan dengan semakin meningkatnya oleoresin, penyalutan menjadi semakin tidak sempurna. Menurut Risch dan Reineccius (1987) faktor utama yang menentukan oil recovery senyawa volatil adalah komponen padatan dalam emulsi oleoresin. Semakin tinggi jumlah padatan, semakin tinggi oil recovery yang dihasilkan karena waktu pembentukan membran semipermeabel di permukaan partikel serbuk saat proses spray drying menjadi berkurang.
Pembentukan membran semipermeabel memungkinkan terjadinya mekanisme difusivitas selektif di mana membran hanya dapat ditembus oleh air sedangkan oleoresin tetap tertahan di dalam membran. Selama penyalutan, senyawa volatil dapat menguap karena terjadi pemanasan dengan suhu yang tinggi. Dalam hal ini peningkatan natrium kaseinat dalam kombinasinya dengan maltodekstrin mempengaruhi hasil pengukuran oil recovery.

Penggunaan natrium kaseinat yang besar meningkatkan kemampuan penyalutan oleoresin, sehingga oil recovery yang dicapai lebih tinggi dibandingkan dengan penggunaan natrium kaseinat yang kecil. Sifatnya sebagai emulsifier tampak jelas dengan memberikan penampilan yang sangat berbeda pada penggunaan natrium kaseinat dalam jumlah kecil $(7,5 \%)$ dan besar (30\%). Data analisis statistik menunjukkan adanya pengaruh yang sangat berbeda nyata terhadap oil recovery antarperlakuan, namun antara perlakuan $\mathrm{O}_{5} \mathrm{~N}_{7,5}-\mathrm{O}_{10} \mathrm{~N}_{7,5}$ dan $\mathrm{O}_{5} \mathrm{~N}_{30^{-}}$ $\mathrm{O}_{10} \mathrm{~N}_{7,5}$ terlihat adanya pengaruh yang nyata. Namun bila dikaitkan antara hasil dan biaya proses, penggunaan oleoresin dengan konsentrasi 10\% memberikan hasil yang lebih baik.

Kestabilan emulsi menjadi suatu hal penting yang perlu diperhatikan untuk mendapatkan efisiensi proses dan hasil yang terbaik. Zat pengemulsi (emulsifier) merupakan komponen yang paling menentukan agar diperoleh emulsi yang stabil (Anief, 1997). Kondisi sistem emulsi pada penelitian ini menunjukkan hasil sebagai berikut:

1. Penggunaan na-kaseinat $7,5 \%$ menghasilkan emulsi yang baik pada jumlah oleoresin $5 \%$ dan 10\%. Namun pada jumlah oleoresin $15 \%$ dan $20 \%$, emulsi tampak pecah. 
2. Penggunaan na-kaseinat $30 \%$ memberikan kestabilan emulsi yang baik pada jumlah oleoresin $5 \%-20 \%$.

Berdasarkan data pada Tabel 4, peningkatan persentase oleoresin akan meningkatkan surface oil. Sedangkan peningkatan na-kaseinat akan menurunkan surface oil. Hal ini terjadi karena penggunaan na-kaseinat $30 \%$ dapat mengikat oleoresin lebih baik sehingga jumlah oleoresin yang tidak tersalut menjadi semakin kecil kadarnya. Grafik surface oil ditunjukkan pada Gambar 5.

Surface oil yang rendah memberikan efisiensi yang lebih baik dibandingkan dengan surface oil yang tinggi karena semakin kecil kadar surface oilnya maka oleoresin yang tersalut semakin banyak, dihitung berdasarkan jumlah bahan yang ditambahkan. Banyaknya surface oil pada mikrokapsul menunjukkan bahwa penyalut tidak memiliki kemampuan yang baik dalam menyalut oleoresin pada konsentrasi yang tinggi karena melampaui titik optimum penyalutan. Dari hasil analisis statistik, diketahui bahwa antara perlakuan $\mathrm{O}_{5} \mathrm{~N}_{7,5}$, $\mathrm{O}_{5} \mathrm{~N}_{30}$, dan $\mathrm{O}_{10} \mathrm{~N}_{7,5}$ tidak menunjukkan pengaruh yang nyata. Dengan demikian, konsentrasi oleoresin $10 \%$ dengan natrium kaseinat 7,5\% memberikan hasil yang sama baik dengan penggunaan oleoresin $5 \%$.

Kadar air mikrokapsul berkisar antara 4,72\% sampai 6,44\%. Kadar air terendah diperoleh pada perlakuan $\mathrm{O}_{15} \mathrm{~N}_{30}$. Kadar air mikrokapsul pada perlakuan $\mathrm{O}_{10} \mathrm{~N}_{7,5}$ juga menunjukkan hasil yang cukup baik, yaitu 4,97\%. Semakin tinggi kadar air maka stabilitas mikrokapsul menjadi semakin menurun. Perolehan kadar air mikrokapsul dipengaruhi juga oleh faktor lingkungan, yaitu tempat penyimpanan.

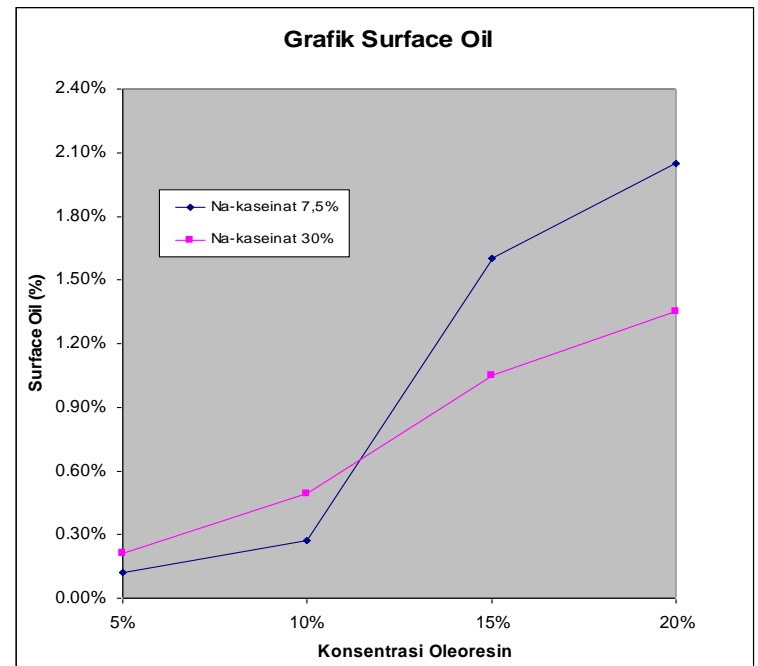

\section{Gambar 5. Grafik Surface Oil} Mikrokapsul Penelitian Utama

Hasil analisa bentuk partikel mikrokapsul oleoresin jahe di bawah scanning electron microscope menunjukkan ukuran dan bentuk partikel yang tidak homogen, seperti terlihat pada Gambar 6. Ukuran partikel mikrokapsul dipengaruhi oleh kecepatan laju alir emulsi oleoresin dan suhu pada proses spray drying.

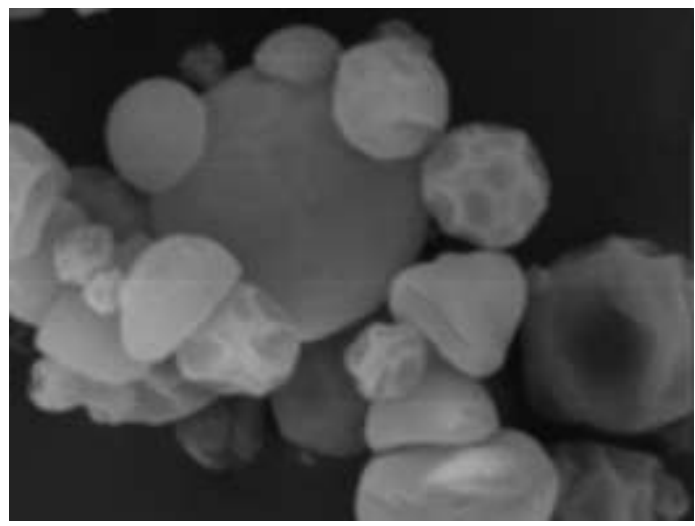

Gambar 6. Bentuk partikel mikrokapsul oleoresin jahe perlakuan $\mathrm{O}_{10} \mathrm{~N}_{7,5}$ di bawah scanning electron microscope, perbesaran 3.500x 
Dalam Gambar 6., nampak bentuk yang bulat penuh, hampir menyerupai bola, bentuk yang berlekuk-lekuk dan ada yang menyerupai bentuk kerucut. Menurut Onwulata et al. (1996) dan Soottitantawat et al. (2005), bentuk partikel yang agak bulat dengan permukaan keriput, tidak mulus dan berlubang-lubang. seperti cekungan adalah bentuk partikel yang biasa terjadi pada proses enkapsulasi menggunakan pati termodifikasi dengan pengering semprot. Bentuk partikel seperti ini disebabkan terjadinya pengkerutan selama proses akhir pengeringan atau pendinginan partikel yang mengandung vakuola udara yang relatif besar (Onwulata et al., 1996).

Vakuola terbentuk ketika air dalam sistem emulsi menguap karena suhu yang tinggi selama proses spray drying dan uap air tersebut kemudian terperangkap dalam kumpulan partikel-partikel oleoresin yang tersalut. Udara yang ada di dalam partikel mikrokapsul akan menekan dinding partikel penyalut untuk bisa keluar. Ada kemungkinan terjadinya pengkerutan saat pendinginan setelah proses spray drying diakibatkan oleh bahan penyalut yang tidak mampu mempertahankan bentuk bulat karena tekanan udara dari dalam partikel tersebut.

Ditambahkan pula oleh Onwulata et al. (1996), bentuk partikel yang seperti ini disebabkan bagian pusat, yaitu komponen flavor, tidaklah berada pada pusat partikel. Akan tetapi komponen flavor berada atau terikat pada dinding matriks, sedangkan bagian pusat partikel kosong. Kekosongan inilah yang mengakibatkan terjadinya cekungan. Model enkapsulasi yang seperti ini dapat diilustrasikan pada Gambar 7.

Idealnya tiap-tiap droplet oleoresin dapat tersalut dengan baik dan terletak di dalam "badan" dinding mikrokap ul, ehingga oil recovery yang didapat akan tinggi. Bila banyak droplet oleoresin yang terletak di permukaan partikel mikrokapsul maka surface oilnya akan menjadi tinggi. Selain posisi pengikatan/penyelaputan oleoresin, surface oil juga dipengaruhi oleh adanya lipatan-lipatan permukaan partikel mikrokapsul yang keriput dan membentuk cekungan. Apabila pada posisi lipatan tersebut terdapat oleoresin, maka komponen volatilnya akan terekspos keluar sehingga surface oil-nya akan tinggi dan oil recovery-nya akan rendah.

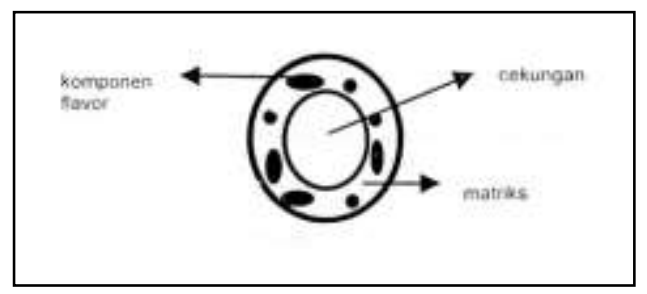

Gambar 7.llustrasi model enkapsulasi dengan pati termodifikasi yang di pengering semprot (Onwulata et al. 1996)

\section{KESIMPULAN}

Dari data-data hasil penelitian ini dapat disimpulkan bahwa:

1. Mikrokapsul oleoresin jahe dapat dibuat dengan metoda spray drying.

2. Konsentrasi oleoresin dan komposisi bahan penyalut berpengaruh sangat nyata terhadap karakteristik mikrokapsul oleoresin jahe (total oil, oil recovery, dan surface oil).

3. Hasil mikrokapsul oleoresin jahe yang terbaik diperoleh pada perlakuan oleoresin $10 \%$ dan natrium kaseinat $7,5 \%$ dengan total oil 2,34\%; oil recovery $87,50 \%$; surface oil $0,27 \%$; dan kadar air 4,97\%.

\section{DAFTAR PUSTAKA}

Anief, Moh. 1997. Ilmu Meracik Obat, Teori dan Praktik. Yogyakarta: Gadjah Mada University Press. Hlm: 132

Departemen Kesehatan Republik Indonesia. 1989. Vademekum Bahan Obat Alam. Jakarta: DepKes RI. Hlm: 78-83. 
Koswara, Sutrisno. 2006. Teknologi Risch, Sara J. and Reineccius, Gary A. Enkapsulasi Flavor RempahRempah. www.ebookpangan.com

Lachman, L., Herbert A. Lieberman., and Joseph L. Kanig. 1970. The Theory and Practice of Industrial Pharmacy, $2^{\text {nd }} E d$. Philadelphia: Lea and Febiger.

Onwulata, C. I., P. W. Smith, P. H. Cooke, and H. G. Holsinger. 1996. Particle Structures of encapsulated milkfat powders. Lebensm. Wiss. Technol. 29: 163-172.

1987. Spray-Dried Orange Oil, Effect of Emulsion Size, Flavor Retention and Shelf Stability. University of Minnesota, St. Paul, MN 55108: Department of Food Science and Nutrition.

Sootitantawat, A., F. Bigeard, H. Yoshii, T. Furuta, M. Okkawara dan P. Linko. 2005. Influence of Emulsion and Powder Stability of Encapsulated D-limonene by Spray Drying. Innovative Food Sci. Emerging Technol. 6: 107-114. 